\title{
Early career guidance: search for advanced formats
}

\author{
M. V. Antonova \\ State Budget Institution of Further Professional Education "Mordovian Republican Institute of Education" \\ MRIE \\ Saransk, Russia \\ mrio@edurm.ru
}

\begin{abstract}
The article attempts to search for advanced formats of conducting early career guidance that meet the requirements of modern economy, parents' and societies' educational needs. The relevance of the issue of competent career guidance in primary school is grounded. The paper presents a review of national psychological and pedagogical research areas on the topic of career guidance for young people. The paper describes principles and advanced ideas which can become defining points in the development of epy career guidance process at the early stage of education. The definition of the socio-pedagogical support for the process of early career guidance is given. The paper brings forward a developed model of socio-pedagogical support for early career guidance. The model takes into account specific patterns of students' socioprofessional self-determination. Some structural elements of the model are characterized, i.e. its goal, tasks, subjects, conditions, principles, methods, implementation process, criteria of efficiency of the process of socio-pedagogical support for early career guidance. Special attention is focused on the description of the process of implementing the regional model of sociopedagogical support for students' early career guidance by means of Children's technopark innovative developing environment, the use of educational and methodological literature that presents didactic characters who possess distinct positive orientations to labour values and standards. The results of the study are practice-oriented and can be used in the school and supplementary education context, in the system of professional training of primary school teachers.
\end{abstract}

Keywords-early career guidance, model of socio-pedagogical support.

\section{INTRODUCTION}

The Russian younger generation lives in challenging and interesting time. High-tech industries of Russia's economy are developing intensively; social differentiation in society is getting more distinct. Old professions tend to disappear giving way to new ones unfamiliar even to some adults.

Today's children live in the epoch of globalization and informatization; they are plunged into the external sociocommunicative environment at a large extent, and "they have to build their own personal trajectories with a great number of potential choices" [1, p. 200]. All this considerably impedes the career choice of school-leavers, makes their life orientations indistinct and makes them confused about their future. They need competent pedagogical support for their professional self-determination.

The relevance of the issue of competent organization of career guidance at different stages of education is emphasized in numerous national psychological, pedagogical and sociological research of the modern time [2-8], etc. The problem of professional self-determination of young people is viewed in historical context (a comparative analysis of popular and effective forms of career guidance used in the last decades, which is conducted nowadays) [3]. Historical comments of the formation of national career guidance practice are presented [9]. Also the paper studies principles of developing value orientation to working professions [10], fulfils the search for up-to-date strategies and resources of development of regional career guidance practice, reveals organizational and methodical mechanisms of these strategies implementation [11, 12]. In addition, it studies axiological aspects of shaping students' professional orientation [13], evaluates the opportunities of using project activity to realize career guidance for primary school children $[14,15]$, etc.

It should be mentioned that the necessity to change the career guidance system is realized at the governmental level $[16,17]$. The authorities' attention to the given problem is largely determined by the state policy which is oriented to intensive science and high technologies development in Russia. In December 2016, the President of Russia V.V. Putin issued a decree that established a long-dated Strategy of scientific and technological development of Russia till the year of 2035. Among the priorities in national science development, the developers of the Strategy pointed out the following:

- digital production technologies;

- $\quad$ creation of new materials;

- development of systems that can process a large amount of information, artificial intelligence and machine learning;

-transition to ecologically clean and resourceconserving sources of energy;

personalized medicine [18].

Undoubtedly, realization of each enumerated direction requires qualified training of highly skilled personnel and, 
consequently, "reloading" of career guidance system and search for advanced formats of its realization which could meet the requirements of modern economy and parents' and societies' educational needs.

In this regard, the Minister of Education and Science of the Russian Federation Olga Vasileva said, "I am deeply confirmed that it is necessary to return orientation to a profession to school. It is essential'. $<\ldots>$ I would like to draw your attention to the task of increasing subject-oriented motivation of school-leavers, i.e. future students, in career choice" [14]. These words were said in MGIMO (Moscow State Institute of International Relations), on a session of Federal educational and methodological association of the integrated group of training specializations "Political sciences and regional studies".

The analysis of the issue showed that modern formats of career guidance are based on the following principles:

the practice-oriented principle (the key instrument of the support of professional self-determination is shaping a child's own experience and elementary professional skills, but not "persuading");

the principle of interdisciplinarity (specialists from different fields are involved in the process of career guidance);

- $\quad$ the principle of social partnership (close cooperation is established between educational organizations of preschool, general, professional, higher, supplementary education; employers and their associations, parents, students, employment services, media, municipal governments and other institutions are involved in the process by means of implementation of on-line programmes);

the principle of use of active and interactive techniques and pedagogical technologies (projects connected with career guidance, professional tryouts, industrial expeditions, professional contests, case-technologies, networking, methods of work with forward-looking materials presented in the Agency for Strategic Initiatives and the Moscow School of Management SKOLKOVO (e.g., The Atlas of Emerging Jobs), etc.).

Primary school must become one of the first stages in providing continuity of the self-determination process. However, methodological and technological solution to this task is not yet reached. That is why work with young schoolchildren and their parents is currently considered to be one of the undeveloped areas of modern career guidance.

Advanced ideas that can become defining points in the development of career guidance at early stages of education are the following:

- the idea of profession-oriented competences;

- the idea of shaping children's readiness to overcome external manipulative influence that can interfere with a career choice;

- the idea of criteria-based evaluation of the efficiency of the support for one's professional self-determination at different age stages;
[19].

the idea of career guidance as a social agreement

In this paper, the authors consider the opportunities of shaping primary school children's socially significant qualities, developing their personal UUD (Universal learning operations) with the help of implementation of the model of socio-pedagogical support for early career guidance.

Karpushina L.P. and Pupkova N.F. define shaping young schoolchildren's socially significant qualities as "pedagogically organized process of developing responsibility, communication skills, independence, creativity, and motivation to continuous personal development which help young schoolchildren successfully adapt to the society and work as its equal members" [20, p.45].

The enumerated qualities serve as a basis of developing personal UUD among which one of the most important structural elements, equally to personal, life selfdetermination, sense formation, moral and ethical orientation, is professional self-determination [21].

Taking into consideration characteristics of pedagogical support varieties brought forward by S. Vasyura and N. Iogolevich [1, p. 209], the authors define socio-pedagogical support for the process of early career guidance as the system of social and pedagogical activity which:

is oriented to the social demand, effective involvement of a child into the system of social and labour relationships, realization of personal potential in the choice of the sphere of professional activity;

implies pooling efforts of all participants of educational process in order to create conditions not only for conscious familiarization of primary school children with modern social and professional context, but also for shaping their value attitude to the world of labour and professions;

is integrated in the system of developing young schoolchildren's UUD;

- gives children an opportunity to express their own reflective and active attitude in the process of gaining personal experience of professionally significant activity.

\section{MODEL OF SOCIO-PEDAGOGICAL SUPPORT FOR THE PROCESS OF EARLY CAREER GUIDANCE}

The career guidance system is in urgent need of developing a model of socio-pedagogical support for the process of early career guidance. Such a model must take into consideration specific patterns of social and professional selfdetermination; i.e.:

- dependence from objective social interests;

- $\quad$ unity and interconnection of the processes of shaping a child's personality and his/her self-development;

- dependence of efficiency of social and professional self-determination from a child's involvement into different kinds of activities [22, p.32]. 
In order to create such a model, it is necessary to point out its structural elements and characterize them.

The most important structural elements of the model are the goal, tasks, subjects, directions, conditions, principles, methods, realization process, and criteria of efficiency of the process of socio-pedagogical support of early career guidance. Let us characterize them.

\section{THE GOAL OF THE MODEL}

The goal consists in assistance of the development of professional self-determination as a structural component of primary school children's UUD, shaping a child's socially adaptive personality that comprises socially significant qualities, realizes intensive cognitive activity in choosing the direction of a future professional work.

\section{THE TASKS OF THE MODEL}

The tasks are the following:

- assistance in the developing primary school children's steady cognitive interest, motivation to familiarizing with the world of professions and to mastering professional skills in innovative areas of human activity;

- $\quad$ assistance in the formation of a child's value attitude to adults' work and results of their professional activity;

assistance in the development of a system of steady views and clear knowledge about the variety and characteristic peculiarities of professions;

assistance in the development of a child's socially significant qualities which are necessary for an effective adaptation to future professional activity;

creation of conditions for developing premises of working activity culture (communication skills to conduct activity in a work collective, elementary practical skills to use tools, etc.).

\section{THE SUBJECTS OF THE MODEL}

The subjects are:

- $\quad$ primary school children;

- school authorities and teaching staff, personnel of supplementary education institutions for children;

- parents.

\section{THE DIRECTIONS OF SOCIO-PEDAGOGICAL SUPPORT}

Pedagogical support is given in two directions:

- individual work that implies socio-pedagogical work directly with a primary school student;

- group work that implies socio-pedagogical work with definite groups of primary school students.

\section{THE CONDITIONS OF REALIZATION}

To realize the developed model it is necessary to create the following conditions:

consideration of age specificity of primary school children (peculiarities of a child's perception of social reality; peculiarities of formation of the system of views about the world; peculiarities of thinking, memory, attention, speech development; peculiarities of communication with competent adults and peers, etc.);

- $\quad$ actualization of value and norm contents and form of presenting school texts from modern textbooks and educational and methodical manuals; school texts are considered to form a positive emotional idea of working activity, the vision of labour as a life value;

creation of innovative developing subject and space environment for a child's personal development; this environment attracts a child's attention to the latest lines of development of scientific and technical, research, technological and engineering activities, as well as contributes to a child's active involvement in different kinds of cultural practices;

- joining children to work that they can do; involving children in different kinds of children's productive activity on the basis of equal interaction between a child and an adult in the process of familiarization with the world of professions;

- adults' support of children's initiative and independence in conducting efficient types of labour, within which the formation of premises of a child's working activity takes place;

- $\quad$ social partnership between an educational institution and a family in regard of a preschooler's working education;

realization of the mechanisms of networking and public-private partnership in regard of working education and early career guidance.

\section{THE PRINCIPLES}

The principles of the model of socio-pedagogical support of early career guidance are the following;

- the principle of vertical integration that implies succession of goals, tasks, pedagogical technologies profession-oriented work at all education levels, their orientation to state and public and economic demand;

- the principle of polysubjectivity that implies multitude of participants of the pedagogical support process (a teacher, a psychologist, parents, a child);

the principle of imagery that determines the specificity of creating a content and information component of socio-pedagogical support of early career guidance, implies compulsory use of image variety (visual, auditory, tactile) that are suitable for children, bright and positive (not dull) "stories about professions" with the description of a profession's characteristics and its peculiarities; the use of this principle will contribute to the development of a positive image of a 
professional (a professional type, a stereotype), emotionally positive attitude to it;

the principle of self-identification that implies the selection of content of the process of early career guidance with orientation not to information (knowledge of a subject) but to activity-oriented content of education with orientation to formation of conscious work experience.

\section{THE METHODS}

The efficiency of developing a child's personal UUD in the process of realization of the model of socio-pedagogical support for early career guidance is determined by the use of active and interactive techniques which are directed to "emotional experiencing and reflective perceiving of information" [23, p. 49] rather than understanding and remembering facts. Such methods include:

- the empathy method based on one's identification with an object of the activity through getting into an image;

- the method of multidimensional matrixes directed to developing a child's ability to solve socio-ethical problems; this method is based on the systematic analysis of new relationships and connections;

- the method of designing, analyzing and solving socio-ethical tasks that implies developing a child's ability to compare his/her own behavior with moral standards;

- $\quad$ the method of simulating real life situations;

- the problem-based method that contributes to advancement of accumulated social knowledge, skills, experience of emotional relationships and creative activity through involving a child into socio-ethical problem solving [23, p. 49].

\section{THE PROCESS OF REALIZATION}

The best option of implementing regional models of socioprofessional orientation of students is Russia's network of Children's technoparks.

The initiative of creating the network of Children's technoparks in all the regions of Russia is realized by the Fund of new forms of education development with the support of Ministry of Education and Science of the Russian Federation and the Agency for strategic initiatives upon the instruction of Russia's President V.V. Putin [24].

One of such technoparks works successfully in the Republic of Mordovia. Its infrastructure enables to organize the process of students' socio-professional self-determination at a high technological level and helps to develop such children's characteristics as:

steady cognitive interest and motivation to master complex high-tech professional skills which require highly developed engineering thinking; realization of social significance of invented products;

- new subject competences (knowledge about recent achievements in electronics, nano- and bio-technologies, programming; knowledge about the peculiarities of working activity in modern areas of science);

experience of working activity, elementary practical skills in the sphere of high technologies (children's participation in realizing the projects on flood monitoring, developing applications for glasses of augmented reality, developing mechanisms for automatization of labour-intensive processes at a factory, creating robotic inspection stations for trucks, developing projects on full life cycle in the sphere of space technologies);

culture of information and reading habits, skills of effective independent research activity;

high social adaptability and a working person's qualities (diligence, responsibility, creativity, ability to follow through and others);

skills of team work, projection of relevance of their inventions on the market (children's teams work in the format of a design office - they estimate their engineering solutions, create $3 \mathrm{D}$-models, produce material objects according to the models and conduct testing) [11, p. 80].

The proof of the effective work of Children's technoparks lies in their pupils' victories in all-Russia and international Olympiads, competitions JuniorSkills, all-Russia engineering Olympiad "The Olympiad of NTI" (National technical initiative).

Another significant aspect of realization of the model of socio-pedagogical support for early career guidance is saturation of educational service market with qualitative educational products for methodical support for the process of early career guidance. All subjects of educational process (i.e. teachers, children, parents) are in urgent need of competent organization and methodical support for the process of making a professional choice. In connection with it a workbook "Introducing jobs" was developed and approved in practice. The development of this educational product is based on the following:

- the conviction that activity-oriented component of socio-pedagogical support for early professional selfdetermination must be expressed by the formation of a child's experience of self-identification with these or those people or imaginary creatures who possess a certain set of qualities and competences significant for professional self-determination; to gain such experience children can deal with specially created didactic heroes who possess distinct positive orientations to labour values and standards;

the results of the analysis of labour values and standards presented in the contents of textbooks for primary school. The analysis conducted by L.A. Okolskaya revealed the following facts: a) labour values and standards are adopted by means of introduction of working characters of school texts to children; these characters appear to be "objects of identification and examples to follow" [25, p. 74]; b) texts from modern textbooks for primary school can be characterized by "weakening of positive emotional association with labour", norms of working enthusiasm and achievements 
have devalued, and, in its turn, brought down the status of labour as an essential life value [25, p. 78].

Within the limits of realization of the regional model of early career guidance Kuigorozh, a character from the workbook "Introducing jobs", has proved to be a positive one. The image of this didactic character is taken from Mordovian mythology. Kuigorozh is a fantastical being who brings home treasure and constantly asks his master for a job to do.

The succession of introducing professions to children is given in the form of profession-oriented fairy-tale; in the development of the plot, Kuigorozh experiences different life situations and children help him to fulfil tasks, make out the peculiarities of different professions, and understand the specificity of working activity better. This plot helps to tell children about the varieties of professions in an easy and entertaining way.

The main advantages of introducing such a didactic hero in an educational space are the following:

introduction of professions to children in a vivid, attractive, emotional form and, thus, easily understood by children;

opportunity to fulfil tasks in different forms of children's activity (getting into a profession in a game, drawing, designing);

- opportunity to practice partnership in the system "child - adult".

The ethnocultural color of this didactic character is used to enhance emotional and visual presentation of the variety of professions to a child, to develop a child's respect for working people and positive image of a professional, to demonstrate the outer distinguishing features of people of this or that occupation, to involve a child in a process of fulfilling practical tasks and a problem-solving process.

The novelty of this educational product consists in:

1) the opportunity to develop motivational and cognitive components of socio-professional orientation at the propaedeutic stage through involving a child into different kinds of cultural practices in the process of fulfilling the tasks from the workbook;

2) integration of the processes of socio-professional orientation and ethno-cultural education of primary school children.

In order to ensure continuity of work on career guidance, there is a number of education products developed which are meant to be used at subsequent stages of schooling. Among these educational products are:

a workbook for a profession-oriented course "Time to choose a profession" for students of the 9th form;

"Career navigator": methodical recommendations for teachers to conduct profession-oriented classes in the 8th and 9th forms;

a workbook on the course "Career navigator" for parents.
The third aspect of implementation of the model of sociopedagogical support for early career guidance consists in the work with parents that implies purposive and complex preparation of parents for playing different social roles which are necessary for their children's career choice:

a parent as an equal subject of socio-pedagogical support for his/her child professional self-determination (a parent is supposed to be knowledgeable, able to critically evaluate prevalent trends of social opinion and his/her own views);

a parent as an equal partner of school in the process of socio-pedagogical support for a child's professional selfdetermination;

a parent as a customer of profession-oriented services; a parent is supposed to formulate a demand competently, to analyze offers on the educational services market, to evaluate their quality and, on this basis, to make a choice.

\section{THE CRITERIA OF EFFICIENCY}

The criteria of efficiency of the presented model are:

- development of children's motivational component of socio-professional orientation (steady interest to the world of professions; positive, value attitude to adults' work and their own working activity; willingness to take part in team working activity together with adults);

- development of children's cognitive component of socio-professional orientation (the system of knowledge and views about the variety and specificity of professions, goals and values of labour in the society and a person's life);

development of children's socially significant qualities (independence, diligence, responsibility for a result, ability to follow through, initiative, creative attitude to working activity, etc.);

- development of premises of working activity culture (ability to organize their own working space effectively, to use different tools and safe methods of performing working activity, establish positive relationships with co-workers, etc.).

\section{CONCLUSION}

Thus, the model of socio-pedagogical support for early career guidance is created on the basis of the systematic and activity-oriented approach and meets the requirements of FGOS NOO (Federal State Educational Standard of Primary General Education) [26] as it supposes:

- upbringing and developing such personality traits which meet the requirements of information society and innovative economy;

content selection and use of education technologies aimed at obtaining socially desired level of primary school children's personal and cognitive development;

- use of interactive methods of organizing educational activity and cooperating of the subjects of educational 
relationships in the process of achieving the goals of personal, social and cognitive development of young schoolchildren;

- consideration of students' age peculiarities, significance of activities and communication forms for developing self-determination as a structural component of personal UUD of primary school children.

The results of the study are practice-oriented and can be used in the school and supplementary education environment, in the system of professional training of primary school teachers.

\section{References}

[1] S. A. Vasyura and N. I. Iogolevich, "Temporal trans-spective of teenagers as a psychological and pedagogical problem," Intergration of education, vol. 21, iss. 2, pp. 199- 217, 2017.

[2] V. I. Blinov, "Differentiation approach requirements for organizational and pedagogical support for students' professional self-determination". Current issues of science and education, Penza, issue 6, 2014 [available at: http://www.science-education.ru/120-16020]

[3] V. I. Revyakina and K.E. Osetrin, "Career guidance at schools: experience of the past and challenges of the present". Tomsk State Pedagogical University Bulletin, issue 5(158), pp. 244-248, 2015.

[4] E. F. Zeer, "Self-determination of the studying youth in modern conflicting realities", Moscow: MPSI Publ., 2015, 100 p

[5] The concept of support of students' professional self-determination in the conditions of continuous education / The centre of professional selfdetermination and qualification systems of Federal Institute of Education Development [available at: http://eduidea.ru/file/document/521]

[6] N. S. Pryazhnikov, "Career guidance at school and college. Games, discussions, tasks, exercises”. Moscow: Akademiya Publ., 2014, 304 p.

[7] K. A. Smirnov, Organizational and pedagogical work with students' families in the process of professional self-determination: some results of empirical research, Eurasian educational dialogue: proc. of international education forum, Yaroslavl': GOAU YAO IRO Publ., 2015, pp. 116-118.

[8] S. N. Chistyakova, N. F. Rodichev and I.S. Sergeev, "Criteria and indications of students' readiness for professional self-determination", Professional education. Capital, issue 8, pp. 10-16, 2016.

[9] A. D. Kopytov, "Career guidance and professional education: a new context of a scientific and pedagogical problem". Tomsk State Pedagogical University Bulletin, issue 12 (177), pp. 60-63, 2016.

[10] N.E. Skripova, "The principles of development of students' value orientation to working professions". Tomsk State Pedagogical University Bulletin, issue 5 (182), pp. 83-86, 2017.

[11] M.V. Antonova and O.I. Maksimkina, "Pedagogical support for the process of socio-professional orientation of primary school children".
Moscow City Pedagogical University Bulletin, part "Pedagogy and psychology“", issue 2 (40), pp. 76-82, 2017.

[12] L.G. Smyshlyaeva and G.Yu. Titova, "Development of regional career guidance practice at school oriented to pedagogical professions: strategy and resources", Tomsk State Pedagogical University Bulletin, issue 5(170), pp. 36-41, 2016.

[13] Yu. N. Malinovskaya and F. I. Kevlya, "Impact of teenagers' value system on formation of their profession orientation". Tomsk State Pedagogical University Bulletin, issue 12 (177), pp. 56-59, 2016.

[14] Z. B. Mukhamedzhanova, "Career guidance for primary school students: project activity opportunities". Primary school, issue 5, pp. 40-41, 2014.

[15] A. M. Cherkasova, "Career guidance for primary school children. Project activity". Primary school, issue 10, pp. 41-43, 2016.

[16] Ol'ga Vasil'eva expressed her opinion about returning career guidance to schools [available at: https://www.ucheba.ru/article/3850\#]

[17] Direct line to Vladimir Putin, 16.04.2015 [available at: http://kremlin.ru/events/president/news/49261]

[18] The Russia's President Decree dated 01.12.2016 N 642 "On the strategy of sceintific and technological development of the Russian Federation" [available at: http://www.consultant.ru/document/cons_doc_LAW_207967/]

[19] M.V. Antonova, "Pedagogical support for primary school children's professional self-determination - an undeveloped area of career guidance", Professional education. Capital, issue 5, pp. 35-38, 2017.

[20] L.P. Karpushina and N. F. Pupkova, "Shaping primary school children's socially significant qualities as a psychological and pedagogical problem". The Humanities and education, issue 1, pp. 42-45, 2016.

[21] A. G. Asmolov, "How to project universal learning operations in primary school: from action to thought", Prosveshchenie Publ., $151 \mathrm{p}$, 2008

[22] A. Ya. Zhurkina, E. G. Sergushin and O.V. Sergushina, "Theoretical aspects of developing socio-profesisonal self-determination of students in educational organizations". Intergration of education, vol. 20, issue 1, pp. 29-36, 2016

[23] I. A. Neyasova, "Development of primary school students' personal universla learning operations in an educational space". The Humanities and education, issue 1, pp. 47-50, 2017.

[24] List of assignments on the results of the meeting of Presidium of RF State Council, held on 25 November 2015 [available at: http://www.kremlin.ru/acts/assignments/orders/50998]

[25] L. A. Okol'skaya, "Labour value and standards in the content of primary school textbooks: today and 20 year ago". Education issues, issue 2, pp. 68- 85, 2007.

[26] Decree of the Ministry of education and science of the Russian Federation, dated 6 October 2009 N 373 "On the approval and launch of the Federal state educational standard of primary general education" (as amended) [available http://base.garant.ru/197127/\#block_2\#ixzz4kFQipVfp] 